\begin{tabular}{|l|l|}
\hline SITAS & JANHUS Journal of Animal Husbandry Science \\
\hline & $\begin{array}{l}\text { Jurnal IImu Peternakan } \\
\text { Fakultas Pertanian, Universitas Garut } \\
\text { ISSN : 2548-7914 }\end{array}$ \\
\hline
\end{tabular}

\title{
IDENTIFIKASI KARAKTERISTIK SIFAT KUANTITATIF KAMBING PERANAKAN ETAWAH BETINA DI KELOMPOK TERNAK MITRA USAHA KECAMATAN SAMARANG KABUPATEN GARUT
}

\section{(Quantitative Traits Identification of Peranakan Etawah Female Goat at Mitra Usaha Livestock Group Samarang Subdistrict Garut Regency)}

\author{
Dani Ramdani ${ }^{1}$, Tendy Kusmayadi ${ }^{2}$ \\ ${ }^{1}$ Dinas Peternakan, perikanan dan Kelautan Kabupaten Garut \\ ${ }^{2}$ Dosen Program Studi Peternakan Fakultas Pertanian Universitas Garut \\ Email : htendy64@gmail.com
}

\begin{abstract}
Abstrak
Penelitian dilaksanakan di Kampung Lengkong Desa Samarang Kecamatan Samarang Kabupaten Garut mulai tanggal 15 sampai 30 Januari 2013. Penelitian bertujuan untuk memperoleh karakteristik sifat kuantitatif kambing Peranakan Etawah betina yang meliputi bobot badan, tinggi pundak, panjang badan, lingkar dada, panjang telinga, dan panjang bulu rewos di Kelompok Ternak Mitra Usaha. Metode yang digunakan dalam penelitian ini adalah metode deskriptif-analitik, penentuan sampel berdasarkan (purposive sampling). Jumlah kambing PE yang diteliti yaitu sebanyak 43 ekor betina tidak bunting berumur dua tahun. Hasil penelitian menunjukkan rata-rata bobot badan $38,9 \pm 0,10 \mathrm{~kg}$ dengan nilai koefisien variasi $4,5 \%$, tinggi pundak 74,9 $\pm 0,53 \mathrm{~cm}$ dengan nilai koefisien variasi $2,9 \%$, panjang badan $60,5 \pm 0,25 \mathrm{~cm}$ dengan nilai koefisien variasi $3,2 \%$, lingkar dada 78,9 $\pm 0,64 \mathrm{~cm}$ dengan nilai koefisien variasi $2,6 \%$. panjang telinga $26,8 \pm 0,40 \mathrm{~cm}$ dengan nilai koefisien variasi 3,8\%, dan panjang bulu rewos 13,9 $\pm 0,24 \mathrm{~cm}$ dengan nilai koefisien variasi $11,6 \%$. Hasil pengujian dengan menggunakan uji t, nilai distribusi ttabel $(1,68)$, dari karakteristik sifat kuantitatif, karakteristik yang sesuai dengan standar SNI adalah panjang badan dengan nilai thitung 1,73, sedangkan karakteristik tidak sesuai standar yang dipersyaratkan SNI, bobot badan dengan nilai thitung -7,85, tinggi pundak dengan nilai thitung $-0,37$, lingkar dada dengan nilai thitung $-6,75$, panjang telinga dengan nilai thitung 1,57 , dan panjang bulu rewos dengan nilai thitung $-0,58$.
\end{abstract}

Kata kunci : Identifikasi, Sifat kuantitatif, Kambing Peranakan Etawa Betina

\section{Abstract}

The Research was conducted at Lengkong Village Samarang Subdistric Garut Regency at 15 until 30 Januari 2013. The objective of research are to identify characterristics of quantitative traits of Peranakan Etawah Female Goat in Mitra Usaha Livestock Group. The quantitative traits are body weight, shoulder height, cest circumference, body lenght, ear length and fur rewos length. Descriptive analytic method was used in this study with purposive sampling using 43 non pregnant peranakan etawa female goat, two years age. Result of research show that average of body weight $(\mathrm{kg})$ were $38,9 \pm 0,10 \mathrm{~kg}$ with variation coefficient $4,5 \%$, shoulder height (cm) were $74,9 \pm 0,53$ with variation coefficient $2,9 \%$, body length $(\mathrm{cm}) 60,5 \pm 0,25$ with variation coefficient $3,2 \%$, chest circumference (cm) 78,9 $\pm 0,64$ with variation coefficient 2,6\%, ear length 
(cm) were 26,8 $\pm 0,40$ with variation coefficient $3,8 \%$, and fur rewos length $(\mathrm{cm}) 13,9 \pm 0,24$ with variation coefficient 11,6\%. Result of examination by using test $t$, assess the distribution ttabel $(1,68)$, characteristic matching with standard SNI is body length with the value ttabel 1,73, while inappropriate characteristic of standard which qualify the SNI, is body weight with the value thitung - 7,85, while shoulder height with the value thitung -0,37, chest circumference with the value thitung - 6,75, ear length with the value thitung - 1,57, and length of fur rewos with the value thitung - 0,58.

Keywords : identification, quantitative traits, Peranakan Etawa female goat

\section{Pendahuluan}

Ternak kambing sebagai salah satu kekayaan sumberdaya genetik lokal di Indonesia belum banyak digali potensinya. Populasi kambing tersebar hampir di seluruh wilayah Indonesia. Populasinya pada tahun 2011 mencapai 3,9 juta ekor atau 30\% dari populasi ternak potong dan perah yang merupakan data jumlah seluruh bangsa kambing yang ada di Indonesia. Salah satu dari bangsa atau jenis kambing tersebut adalah kambing Peranakan Etawah (PE) yang populasinya mencapai 500.000 ekor (Direktorat Jenderal Peternakan dan Kesehatan Ternak, 2011).

Kambing Peranakan Etawah (PE) yaitu bangsa kambing yang diperoleh dari kawin tatar (grading-up) antara kambing asli Indonesia (kambing kacang) dengan kambing Etawah yang didatangkan dari India. Pemeliharaan kambing PE di Indonesia ditujukan untuk penghasil daging dan susu (dual purpose). Pemeliharaan kambing PE sebagai ternak penghasil daging dan susu memiliki potensi yang cukup tinggi karena memiliki kemampuan adaptasi yang luas, yaitu dari daerah tropis hingga subtropis, sehingga mampu beradaptasi dengan baik terhadap iklim yang ada di Indonesia.

Ciri khas dari Kambing Peranakan Etawah atau PE adalah pada bentuk mukanya yang cembung, bertelinga panjang yang menggantung dan ujungnya sedikit melipat, postur tubuh tinggi. Warna rambut kambing PE terdiri atas kombinasi coklat sampai hitam atau abu-abu dan muka cembung (Hardjosubroto, 1994). Kambing PE jantan berbulu di bagian atas dan bawah leher, rambut pundak dan paha belakang lebih lebat dan panjang. Kambing PE betina memiliki rambut panjang (rewos) hanya pada bagian paha belakang.

Kambing PE merupakan kambing yang relatif subur untuk beranak kembar (Budiarsana, 2005). Karakteristik Kambing Peranakan Etawah (PE) menurut Markel dan Subandryo (1997) adalah kuping menggantung ke bawah dengan panjang 18-19 cm, tinggi badan antara 75-100 cm, bobot jantan sekitar $40 \mathrm{~kg}$ dan betina sekitar $35 \mathrm{~kg}$. Bobot lahir 2,4 sampai 2,6 $\mathrm{kg}$ dan berat sapih 9 sampai $11 \mathrm{~kg}$ pada umur 90 sampai 120 hari, biasanya bobot lahir anak jantan lebih tinggi dibandingkan dengan anak betina. Dikemukakan Subandriyo (2004), kambing PE ini merupakan tipe dwiguna yaitu sebagai penghasil susu dan daging, dan antara kambing jantan PE dan kambing betina PE memiliki performan yang berbeda dalam sifat kuantitatifnya.

Di Kabupaten Garut berdasarkan data dari Dinas Peternakan Kabupaten Garut tahun 2011 populasi kambing PE sebanyak 2349 ekor atau 3\% dari jumlah populasi ternak kambing yang ada di Kabupaten Garut (Disnakanla Kabupaten Garut, 2011). Budidaya kambing PE di Kabupaten Garut berkembang belum lama, yang dipelihara sebagai ternak penghasil susu dan daging. Pada umumnya kambing yang dipelihara sebagian besar adalah kambing betina, karena jumlah 
kambing jantan hanya untuk pemacek, selebihnya dijual sebagai ternak potong terutama menjelang hari-hari besar keagamaan.

Mengingat besarnya peranan kambing betina dalam proses pewarisan genetik serta kompleksnya faktor yang mempengaruhi performan kambing PE betina, maka penelitian mengenai karakteristik sifat kuantitatif kambing PE betina secara langsung di lapangan menjadi penting untuk dilakukan. Ukuran-ukuran tubuh seperti bobot badan, tinggi pundak, panjang badan, lingkar dada, panjang telinga, dan panjang bulu rewos mempunyai arti penting karena dapat memberikan gambaran tentang karakteristik sifat kuantitatif kambing PE betina di Kabupaten garut umumnya,khususnya di Kelompok Ternak Mitra Usaha Kampung Lengkong Desa Samarang, Kecamatan Samarang, Kabupaten Garut.

Berdasarkan uraian tersebut di atas, maka dapat dikemukakan identifikasi masalah sebagai berikut : Bagaimanakah karakteristik sifat kuantitatif kambing PE betina di Kelompok Ternak Mitra Usaha, Kampung Lengkong Desa Samarang Kecamatan Samarang Kabupaten Garut. Penelitian ini bertujuan untuk memperoleh gambaran mengenai karakteristik sifat kuantitatif kambing PE betina di Kelompok Ternak Mitra Usaha, Kampung Lengkong Desa Samarang Kecamatan Samarang Kabupaten Garut.

\section{Metodologi}

\subsection{Objek Penelitian}

Kambing Peranakan Etawa betina yang tidak sedang bunting berjumlah 43 ekor di kelompok ternak Mitra Usaha. Penentuan sampel ternak kambing sebagai bahan penelitian dilakukan dengan cara ditentukan (purposive sampling), dengan menentukan seluruh ternak kambing PE yang sudah berumur lebih dari dua tahun, yaitu kambing betina dewasa yang tidak sedang bunting.

\subsection{Pengukuran Bagian Tubuh}

Ukuran tubuh kambing PE diperoleh langsung dengan cara mengukur peubah ukuran tubuh yang diamati yaitu bobot badan, lingkar dada, panjang badan, tinggi pundak, panjang telinga dan panjang bulu rewos.

\subsection{Metodologi Penelitian}

Metode penelitian yang digunakan adalah metode deskriptif analitik. Metode penelitian ini digunakan untuk mendeskripsikan temuan data sebagaimana mestinya untuk memperoleh data yang diperlukan, yaitu sifat kuantitatif kambing PE.

\section{$3 \quad$ Hasil dan Pembahasan}

\section{Karakteristik Bobot Badan Kambing PE Betina}

Pengukuran bobot badan kambing PE betina di Kelompok Ternak Mitra Usaha dilakukan dengan cara kambing ditimbang dengan menggunakan timbangan manual kapasitas $100 \mathrm{~kg}$ dengan ketelitian $0,1 \mathrm{~kg}$. Hasil pengukuran terhadap bobot badan pada 43 ekor kambing yang diamati disajikan pada Tabel 1 . 
Tabel 1. Karakteristik Bobot Badan Kambing PE Betina

\begin{tabular}{llc}
\hline No. & \multicolumn{1}{c}{ Nilai } & Bobot Badan \\
\hline 1. & Rata-rata Sampel & 38,9 \\
2. & Simpangan Baku Sampel & 1,75 \\
3. & Koefisien Variasi Sampel & 4,51 \\
4. & Standar Error Populasi & 0,47 \\
5. & Rata-rata populasi & $38,90 \pm 0,10$ \\
6. & $\mathrm{t}_{\text {tabel }}(95 \%)$ & 1,68 \\
7. & $\mathrm{~T}_{\text {hitung }}$ & $-7,85$ \\
\hline
\end{tabular}

Hasil pengamatan menunjukkan bahwa rata-rata bobot badan kambing PE di Kelompok Ternak Mitra Usaha adalah 38,9 $\pm 0,10 \mathrm{~kg}$. Rata-rata bobot badan kambing tersebut lebih rendah dibandingkan dengan bobot badan kambing PE betina yang memenuhi persyaratan SNI yaitu $41,9 \pm 7 \mathrm{~kg}$. Koefisien variasi menunjukkan angka 4,5\% yang berarti bobot kambing PE yang diamati relatif seragam, karena nilai koefisien variasi masih di bawah 5\%. Sedangkan hasil pengujian dengan uji t diperoleh nilai thitung $-7,85$, nilai thitung $<\mathrm{t} \_\alpha / 2$, maka $\mathrm{H} 0$ diterima dan H1 ditolak, yang artinya terdapat perbedaan antara rata-rata bobot kambing PE hasil pemeliharaan dengan SNI. Hasil pengujian dapat dikemukakan bahwa rata-rata bobot kambing PE yang dipelihara Kelompok Peternak Mitra Usaha memiliki bobot badan yang nyata lebih rendah dari rata-rata standar.

Secara keseluruhan kambing PE yang diteliti menunjukkan performa badan yang kurus, yang menyebabkan rata-rata bobot kambing yang lebih rendah. Rendahnya bobot badan kambing PE yang dipelihara Kelompok Ternak Mitra Usaha disebabkan berbagai faktor yang mempengaruhi pertumbuhan kambing tersebut, terutama tingkat perkembangan ternak yang dipengaruhi manajemen pemeliharaan, khususnya dalam pemberian pakan dan pemeliharan kesehatan ternak. Pakan yang diberikan adalah jenis hijauan, sedangkan konsentrat jarang diberikan. Ketersediaan hijauan makanan ternak yang dikonsumsi oleh kambing PE untuk kelangsungan pertumbuhan sangat berpengaruh terhadap pertambahan bobot badan setiap harinya. Manajemen pemeliharaan ini berkaitan dengan pengalaman sebagian anggota kelompok yang belum banyak pengalaman dalam memelihara kambing PE, karena kelompok ternak Mitra Usaha dalam memelihara kambing PE termasuk masih baru, yaitu sejak adanya bantuan dari pemerintah, yaitu tahun 2010 sehingga menejemennya masih kurang baik.

Faktor lingkungan inilah yang jelas mempengaruhi bobot badan kambing PE betina di kelompok Mitra Usaha terutama adalah pakan. Kambing hanya diberikan pakan hijauan berupa rumput lapangan yang kandungan gizinya rendah. Ternak kambing juga tidak diberikan konsentrat sehingga pertumbuhannya kurang terpacu. Hal inilah yang menyebabkan bobot badan kambing PE betina lebih rendah jika dibandingkan dengan standar bobot badan SNI

\section{Karakteristik Tinggi Pundak Kambing PE Betina}

Pengukuran tinggi pundak kambing PE betina di Kelompok Ternak Mitra Usaha dilakukan dengan cara mengukur bagian tertinggi pundak dari permukaan tanah menggunakan tongkat ukur satuan centimeter dengan ketelitian 0,1 centimeter. Hasil pengukuran terhadap tinggi pundak pada 43 ekor kambing yang diamati disajikan pada Tabel 2. 
Tabel 2. Karakteristik Tinggi Pundak Kambing PE Betina

\begin{tabular}{clc}
\hline No. & \multicolumn{1}{c}{ Nilai } & Tinggi Pundak \\
\hline 1. & Rata-rata Sampel & 74,9 \\
2. & SimpanganBaku Sampel & 2,2 \\
3. & Koefisien Variasi Sampel & 4,51 \\
4. & Standar Error Populasi & 0,73 \\
5. & Rata-rata populasi & $74,9 \pm 0,53$ \\
6. & $\mathrm{t}_{\text {tabel }}(95 \%)$ & 1,68 \\
7. & $\mathrm{t}_{\text {hitung }}$ & $-0,37$ \\
\hline
\end{tabular}

Hasil pengamatan menunjukkan bahwa rata-rata tinggi pundak kambing PE di Kelompok Ternak Mitra Usaha adalah 74,9 $\pm 0,53 \mathrm{~cm}$. Rata-rata tinggi pundak tersebut lebih rendah namun mendekati nilai tinggi pundak kambing PE betina yang memenuhi persyaratan SNI yaitu $75 \pm 5$ $\mathrm{cm}$. Koefisien variasi menunjukkan angka 2,9\% yang berarti tinggi pundak kambing PE yang diamati relatif seragam, karena nilai koefisien variasi masih di bawah 5\%.

Berdasarkan hasil pengujian pada Tabel 5 diperoleh thitung $<\mathrm{t} \_\alpha / 2$, sehingga Ho diterima, dengan demikian tinggi pundak kambing PE di Kelompok Ternak Mitra Usaha lebih kecil dari standar SNI. Hal ini bisa disebabkan karena pengaruh seleksi awal pemilihan bibit yang kurang baik, yang berkaitan dengan faktor genetik dan kemampuan dalam beradaptasi dengan lingkungan.

Tinggi pundak merupakan salah satu faktor penting dalam pemilihan bibit kambing PE, karena akan berpengaruh terhadap produksi daging dan susu yang dihasilkan. Menurut Sugeng (1993),ukuran tinggi pundak hewan banyak kegunaannya , karena dapat digunakan untuk menaksir bobot hidup maupun bobot karkasnya, serta dapat dijadikan dasar seleksi. Selain itu tinggi pundak dapat memberikan gambaran hubungan morfogenetik, dan dapat digunakan pula dalam memberi gambaran bentuk tubuh hewan sebagai ciri khas bangsa ternak tertentu.

\section{Karakteristik Panjang Badan Kambing PE Betina}

Pengukuran panjang badan kambing PE betina di Kelompok Ternak Mitra Usaha dilakukan dengan cara mengukur jarak garis lurus dari tulang processus spinosus dari vertebrae thoracalios tertinggi sampai benjolan tulang tapis/tulang duduk (osichimus) yang dinyatakan dengan satuan $\mathrm{cm}$. Hasil pengukuran terhadap panjang badan pada 43 ekor kambing yang diamati disajikan pada Tabel 3.

Tabel 3. Karakteristik Panjang Badan Kambing PE Betina

\begin{tabular}{clc}
\hline No. & \multicolumn{1}{c}{ Nilai } & Panjang Badan \\
\hline 1. & Rata-rata Sampel & 60,5 \\
2. & Simpangan Baku Sampel & 1,9 \\
3. & Koefisien Variasi Sampel & 3,2 \\
4. & Standar Error Populasi & 0,56 \\
5. & Rata-rata populasi & $60,5 \pm 0,25$ \\
6. & $\mathrm{t}_{\text {tabel }}(95 \%)$ & 1,68 \\
7. & $\mathrm{t}_{\text {hitung }}$ & 1,73 \\
\hline
\end{tabular}


Hasil pengamatan menunjukkan bahwa rata-rata panjang badan kambing PE betina di Kelompok Ternak Mitra Usaha adalah $60,5 \pm 0,25 \mathrm{~cm}$. Rata-rata panjang badan tersebut lebih tinggi dibandingkan dengan panjang badan kambing PE betina yang memenuhi persyaratan SNI yaitu $60 \pm 5 \mathrm{~cm}$. Koefisien variasi menunjukkan angka 3,2\% yang berarti panjang badan kambing PE yang diamati relatif seragam, karena nilai koefisien variasi masih di bawah 5\%.

Berdasarkan hasil pengujian pada Tabel 6 diperoleh thitung $<\mathrm{t} \_\propto / 2$ sehingga Ho ditolak, dengan demikian panjang badan kambing PE di Kelompok Ternak Mitra Usaha lebih kecil dari standar SNI. Angka tersebut menunjukkan panjang badan kambing PE betina yang dipelihara belum memenuhi standar SNI yang dipersyaratkan. Hal ini diduga bahwa panjang badan yang belum sesuai dengan ukuran rata-rata panjang badan yang dipersyaratkan disebabkan faktor lingkungan.

Sifat kuantitatif panjang badan ini merupakan hasil proses pertumbuhan berkesinambungan dengan setiap bagian tubuh lainnya. Pola panjang badan kambing PE betina yang diamati diduga erat kaitannya dengan pertumbuhan kerangka tubuh, dimana ukuran-ukuran tubuh serta komponen-komponen tubuh merupakan suatu keseimbangan biologis. Sesuai dengan yang dikemukakan Alipah (2002) bahwa panjang badan menggambarkan perkembangan tulang belakang yang terdiri dari tulang punggung, tulang pinggang, dan tulang kelangkang, yang berkaitan dengan perkembangan komponen lainnya. Hal tersebut sangat dipengaruhi oleh faktor genetik dan lingkungan dari ternak tersebut. Lingkungan yang memberikan pengaruh terhadap panjang badan, antara lain pakan/feeding yang diberikan seperti hijauan dan konsentrat, dimana pakan tersebut sebagai komponen ransum kambing PE yang merupakan sumber zat-zat makanan yang dibutuhkan untuk berbagai fungsi tubuhnya, dalam hal ini pertumbuhan.

\section{Karakteristik Lingkar Dada Kambing PE}

Pengukuran lingkar dada kambing PE betina di Kelompok Ternak Mitra Usaha dilakukan dengan cara mengukur lingkar rongga dada yang diukur melalui os scapula menggunakan pita ukur satuan $\mathrm{cm}$ dengan ketelitian $0,1 \mathrm{~cm}$. Hasil pengukuran terhadap lingkar dada pada 43 ekor kambing yang diamati disajikan pada Tabel 4.

Tabel 4. Karakteristik Lingkar Dada Kambing PE

\begin{tabular}{clc}
\hline No. & \multicolumn{1}{c}{ Nilai } & Lingkar Dada \\
\hline 1. & Rata-rata Sampel & 78,9 \\
2. & Simpangan Baku Sampel & 2,1 \\
3. & Koefisien Variasi Sampel & 2,56 \\
4. & Standar Error Populasi & 0,66 \\
5. & Rata-rata populasi & $78,9 \pm 0,64$ \\
6. & $\mathrm{t}_{\text {tabel }}(95 \%)$ & 1,68 \\
7. & $\mathrm{t}_{\text {hitung }}$ & $-6,75$ \\
\hline
\end{tabular}

Hasil pengamatan menunjukkan bahwa rata-rata lingkar dada kambing PE betina di Kelompok Ternak Mitra Usaha adalah 78,9 $\pm 0,64 \mathrm{~cm}$. Rata-rata lingkar dada tersebut lebih rendah dibandingkan dengan lingkar dada kambing PE betina yang memenuhi persyaratan SNI yaitu $81 \pm 5 \mathrm{~cm}$. Koefisien variasi menunjukkan angka 2,6\% yang berarti lingkar dada kambing PE yang diamati relatif seragam, karena nilai koefisien variasi masih di bawah 5\%, sedangkan berdasarkan hasil pengujian pada Tabel 7 diperoleh thitung $<\mathrm{t} \_\alpha / 2$ sehingga Ho diterima, dengan 
demikian lingkar dada kambing PE di Kelompok Ternak Mitra Usaha lebih kecil dari standar SNI.

Ukuran lingkar dada yang relatif seragam dari kambing PE yang diamati disebabkan oleh banyak faktor. Antara lain pakan yang diberikan relatif sama dengan bentuk kandang yang sama. Lingkar dada berpengaruh pada nilai eksterior kambing tersebut, karena dengan nilai lingkar dada yang sesuai atau baik akan mempengaruhi pada cara berdiri ternak. Kandang merupakan salah satu faktor yang paling berpengaruh pada pembentukan lingkar dada, sebab bentuk atau posisi kandang yang tidak sesuai akan mengakibatkan perubahan posisi tegak ternak. Ukuran kandang untuk setiap ekor kambing PE rata-rata adalah kambing PE betina $1 \mathrm{~m} 2 \times 1,2 \mathrm{~m} 2$ dengan tinggi $1,7 \mathrm{~m}$, sehingga cukup ideal untuk pertumbuhan kambing.

\section{Karakteristik Panjang Telinga Kambing PE Betina}

Pengukuran panjang telinga kambing PE betina di Kelompok Ternak Mitra Usaha dilakukan dengan cara mengukur jarak antara pangkal sampai ke ujung telinga menggunakan pita ukur satuan $\mathrm{cm}$ dengan ketelitian $0,1 \mathrm{~cm}$. Hasil pengukuran terhadap panjang telinga pada 43 ekor kambing yang diamati disajikan pada Tabel 5.

Tabel 5. Karakteristik Panjang Telinga Kambing PE Betina

\begin{tabular}{clc}
\hline No. & \multicolumn{1}{c}{ Nilai } & Panjang Telinga \\
\hline 1. & Rata-rata Sampel & 26,8 \\
2. & Simpangan Baku Sampel & 1,0 \\
3. & Koefisien Variasi Sampel & 3,8 \\
4. & Standar Error Populasi & 0,16 \\
5. & Rata-rata populasi & $26,8 \pm 0,60$ \\
6. & $\mathrm{t}_{\text {tabel }}(95 \%)$ & 1,68 \\
7. & $\mathrm{t}_{\text {hitung }}$ & $-0,25$ \\
\hline
\end{tabular}

Hasil pengamatan menunjukkan bahwa panjang telinga kambing PE betina di Kelompok Ternak Mitra Usaha adalah 26,8 $\pm 0,6 \mathrm{~cm}$. Ukuran panjang telinga tersebut lebih pendek dibandingkan dengan ukuran panjang telinga kambing PE betina yang memenuhi persyaratan SNI yaitu $27 \pm 3 \mathrm{~cm}$. Ukuran panjang telinga kambing PE yang diamati sudah memenuhi persyaratan SNI. Koefisien variasi menunjukkan angka 3,8\% yang berarti panjang telinga kambing PE yang diamati relatif seragam, karena nilai koefisien variasi di bawah 5\%.

Berdasarkan hasil pengujian pada Tabel 8 diperoleh thitung $<\mathrm{t} \_\alpha / 2$ sehingga Ho diterima, dengan demikian panjang telinga kambing PE di Kelompok Ternak Mitra Usaha lebih kecil dari standar SNI. Panjang telinga kambing PE yang dipelihara Kelompok Ternak Mitra Usaha meskipun dibawah standar SNI, tapi nilainy simpangannya hanya sedikit dan hal ini diduga disebabkan pengaruh seleksi awal pemilihan bibit yang kurang baik, yaitu bibit yang belum memenuhi persyaratan SNI.

\section{Karakteristik Panjang Bulu Rewos Kambing PE Betina}

Pengukuran panjang bulu rewos kambing PE betina di Kelompok Ternak Mitra Usaha dilakukan dengan cara mengukur dari pangkal bulu sampai ke ujung bulu dari bagian paha dengan menggunakan pita ukur dalam satuan $\mathrm{cm}$ dengan ketelitian $0,1 \mathrm{~cm}$. Hasil pengukuran terhadap panjang bulu rewos pada 43 ekor kambing yang diamati disajikan pada Tabel 6 . 
Tabel 6. Karakteristik Panjang Bulu Rewos Kambing PE

\begin{tabular}{clc}
\hline No. & \multicolumn{1}{c}{ Nilai } & Panjang Bulu Rewos \\
\hline 1. & Rata-rata Sampel & 13,9 \\
2. & Simpangan Baku Sampel & 1,6 \\
3. & Koefisien Variasi Sampel & 11,6 \\
4. & Standar Error Populasi & 0,39 \\
5. & Rata-rata populasi & $13,9 \pm 0,24$ \\
6. & $\mathrm{t}_{\text {tabel }}(95 \%)$ & 1,68 \\
7. & $\mathrm{t}_{\text {hitung }}$ & $-0,14$ \\
\hline
\end{tabular}

Hasil pengamatan menunjukkan bahwa panjang bulu rewos kambing PE betina di Kelompok Ternak Mitra Usaha adalah 13,9 $\pm 0,24 \mathrm{~cm}$. Koefisien variasi menunjukkan angka $11,6 \%$ yang berarti panjang bulu rewos kambing PE yang diamati beragam, karena nilai koefisien variasi berada di atas 5\%. Berdasarkan hasil pengujian pada Tabel 8 diperoleh thitung $<\mathrm{t} \_\alpha / 2$ sehingga Ho diterima, dengan demikian panjang bulu rewos kambing PE di Kelompok Ternak Mitra Usaha lebih rendah dari standar SNI.

Nilai koefisien variasi rata-rata panjang bulu rewos menunjukkan ukuran yang beragam. Setiap kambing betina yang diamati memiliki panjang bulu rewos yang berbeda. Panjang bulu rewos minimum adalah 10,4 cm, sedangkan panjang bulu rewos maksimum adalah 17,89 $\mathrm{cm}$. Keragaman karakteristik beberapa sifat kuantitatif yang terdapat pada kambing PE betina disebabkan dua faktor, yaitu keragaman yang disebabkan oleh lingkungan dan keragaman yang disebabkan oleh sifat yang diwariskan atau genetik.

Respon gen kambing terhadap faktor-faktor lingkungan biasanya terlihat pada penampakan fenotipe dari kambing yang bersangkutan. Sifat gen tersebut akan menentukan potensi karakter, sedangkan lingkungan akan menentukan sampai dimana batas potensi itu. Pada dasarnya keadaan genetik kambing dapat dikatakan relatif lebih stabil dibandingkan dengan keadaan fenotipenya yang sering berubah-ubah seiring dengan keadaan lingkungannya atau cara pemeliharaannya.

Berdasarkan hal tersebut panjang bulu rewos pada kambing betina yang yang dipelihara Kelompok Ternak Mitra Usaha disebabkan oleh faktor lingkungan dan genetik, dimana kambing PE betina yang merupakan hasil keturunan dari induk yang berbeda akan memberikan penampilan fenotipe yang berbeda, sekalipun pada kondisi lingkungan yang seragam. Dengan demikian adanya perbedaan sifat genetik tersebut menyebabkan interaksi dengan lingkungan setempat akan berbeda pula, yang menyebabkan terjadinya perbedaan terhadap karakteristik sifat kuantitatif. Oleh karena perbedaan itu maka setiap gen akan memberikan penampilan fenotipik yang berbeda, yaitu karakteristik kuantitatif yang berbeda.

\section{$4 \quad$ Kesimpulan}

Berdasarkan hasil penelitian mengenai identifikasi karakteristik sifat kuantitatif kambing Peranakan Etawah betina di Kelompok Ternak Mitra Usaha Desa Samarang Kecamatan Samarang Kabupaten Garut dapat disimpulkan : Rata-rata bobot badan 38,9 \pm 0,10 kg dengan nilai koefisien variasi $4,5 \%$, tinggi pundak $74,9 \pm 0,53 \mathrm{~cm}$ dengan nilai koefisien variasi $2,9 \%$, panjang badan $60,5 \pm 0,25 \mathrm{~cm}$ dengan nilai koefisien variasi $3,2 \%$, lingkar dada 78,9 $\pm 0,64 \mathrm{~cm}$ 
dengan nilai koefisien variasi $2,6 \%$. panjang telinga $26,8 \pm 0,40 \mathrm{~cm}$ dengan nilai koefisien variasi $3,8 \%$, dan panjang bulu rewos $13,9 \pm 0,24 \mathrm{~cm}$ dengan nilai koefisien variasi $11,6 \%$.

Hasil pengujian dengan menggunakan uji t, nilai distribusi ttabel $(1,68)$, dari karakteristik sifat kuantitatif, karakteristik yang sesuai dengan standar SNI adalah panjang badan dengan nilai thitung 1,73, sedangkan karakteristik tidak sesuai standar yang dipersyaratkan SNI, bobot badan dengan nilai thitung $-7,85$, tinggi pundak dengan nilai thitung $-0,37$, lingkar dada dengan nilai thitung $-6,75$, panjang telinga dengan nilai thitung $-1,57$, dan panjang bulu rewos dengan nilai thitung $-0,58$.

\section{$5 \quad$ Daftar Pustaka}

Alipah, S. (2002). Hubungan antara Ukuran-ukuran Tubuh dengan Bobot Badan Kambing Peranakan Etawa Umur 6-10 Bulan di Kecamatan Kaligesing Kabupaten Purworejo. Thesis. Fakultas Peternakan Universitas Diponegoro, Semarang..

Badan Standarisasi Nasional Indonesia. (2008). Bibit Kambing Peranakan Etawa (PE). SNI 7325:2008.

Budiarsana, M. (2005). Performan Kambing Peranakan Etawah (PE) di Lokasi Agroekosostem yang Berbeda dalam "Seminar Nasional Teknologi Peternakan dan Veteriner 2005". Balai Penelitian Ternak, Bogor.

Disnakanla Kabupaten Garut. (2011). Kabupaten Garut dalam Angka. Dinas Perternakan Perikanan dan Kelautan Kabupaten Garut.

Direktorat Jenderal Peternakan dan Kesehatan Ternak. (2011). Statistik Peternakan 2008. Direktorat Jenderal Peternakan Departemen Pertanian RI, Jakarta.

Devendra, C. \& M. Bums. (1994). Produksi Kambing di Daerah Tropis. Penerbit ITB Bandung. Bandung.

Hardjosubroto, W. (1994). Aplikasi Pemuliabiakan Ternak di Lapangan. PT Gramedia Widya Sarana Indonesia, Jakarta.

Markel, R. C. dan Subandriyo. (1997). Sheep and Goat Production Handbook for Southeast Asia. 3rd ed. CV Ekha Putra, Bogor.

Subandriyo. (2004). Potensi dan Produktivitas Ternak Kambing Di Indonesia."Proceding Lokakarya Potensi dan Pengembangan Ternak Kambing di Wilayah Indonesia Bagian Timur'.Dinas Peternakan Provinsi Daerah Tingkat I Jawa Timur. 